\title{
MEZI VESNICÍ A VRCHNOSTENSKÝM SÍDLEM. DVORY NA STŘEDOVĚKÉM CHRUDIMSKU
}

\author{
JAN MUSIL - PETR NETOLICKÝ
}

\begin{abstract}
Abstrakt: Sídlištni sit’ Železných hor ve středověku a raném novověku byla tvořena zejména vesnickým osídlením. Řídce se vyskytující městečka tvořila hospodářská a tržní centra většich územních celkủ. Sídlištní strukturu doplňovaly hospodářské dvory. Přispěvek na několika dobře dokumentovaných príkladech z železnohorského regionu představuje základni typy hospodářských dvorů - samostatně stojici hospodářské dvory zahuštujici řidši sidlištni strukturu, samostatně stojíci hospodářské dvory vzniklé redukci větši vsi, hospodářské dvory vázané na feudální sídlo: a) na tvrz; b) na hrad (z této posledně zmiňované varianty se mohlo vyvinout i poddanské městečko).
\end{abstract}

Kličová slova: středověk - raný novověk - vesnice-dvưr-Železné hory.

\section{Between a Village and an Aristocratic Seat. Courtyards in the Chrudim Region in the Middle Ages}

\begin{abstract}
The settlement network in the Železné hory mountains in the Middle Ages and the early modern period mainly consisted of rural settlements. Small towns were sparse and made up economic and market centres of larger areas. The settlement structure was supplemented with courtyards. This article presents, on several well-documented examples from the Železné hory region, the basic types of courtyards: solitary courtyards filling the thin settlement structure, solitary courtyards that came into existence through the reduction of villages, and courtyards linked to feudal estates, i.e. manors or castles (the latter variant sometimes evolved into feudal towns).
\end{abstract}

Key words: Middle Ages - early modern period - village-courtyard-Železné hory mountains.

\section{1 Úvod}

Studiu raně a vrcholně středověkého osídlení na Chrudimsku se věnuje poměrně velké množství badatelů z různých regionálních i nadregionálních institucí. Za současný stav poznání středověkého vesnického osídlení v severní nížinaté části Chrudimska vděčíme především systematickým povrchovým sběrům, které vcelku dobře mapují kontinuitu a diskontinuitu od raně středověkého osídlení až po současnost, doplněným o četné historické prameny (pro severní část Chrudimska srov. Frolík-Sigl 1995). Nicméně k ověření informací získaných nedestruktivními metodami dochází jen zrŕ́dka, při výkonu archeologické památkové péče. Badatelsky nebo preventivně orientované destruktivní archeologické výzkumy se zaměřily jen na místa zejména současných aglomeračních center regionu (např. Chrudim - přehledné shrnutí viz Frolík-Sigl 1998; Předhradí - shrnutí stavu poznání viz Frolík-Musil 2012; Hrochův Týnec - shrnutí stavu poznání viz Frolík-Musil 2011; Hlinsko - Frolík 1989; Skuteč - shrnutí stavu poznání viz Voráček et al. 2011, 10-20; Luže - shrnutí stavu poznání viz Voráček et al. 2010, 28-38); nálezy z venkovského prostředí jsou velmi vzácné (např. Dvakačovice - nepublikovaný soubor). Značně torzovitý je stav našeho poznání středověkého a raně novověkého vesnického osídlení a jeho hospodářského zázemí v převážně zalesněné jižní části Chrudimska, zejména v oblasti Železných hor a Žd'árských vrchů (k současnému stavu poznání viz Musil-Netolický 2014). Mnohem větší pozornost byla $\mathrm{v}$ minulosti věnována studiu feudálních opevněných sídel a jiné fortifikační architektury. První drobné, ale podnětné práce a archeologické výzkumy antropogenních reliktů v rozsáhlých lesních komplexech Chrudimska souvisejících s vesnickým osídlením a hospodářským zázemím byly publikovány teprve nedávno (Frolík 1989a; Musil 2007; 2011; 2011a; Musil-Netolický 2012; 2013; 2014; 2015; 2015a; v tisku). Některé antropogenní relikty a lokality spojené např. s rýžováním zlata byly mylně zařazeny do laténského období (srov. Musil-Netolický 2014a; 2014c; 2015a).

V souvislosti s plněním dlouhodobého vědeckovýzkumného úkolu zaměřeného na poznání osídlení od pravěku po raný novověk na území okresu Chrudim se od roku 2008 výzkumu nemovitých kulturních památek systematicky věnuje Regionální muzeum v Chrudimi ve spolupráci 
s Katedrou archeologie Západočeské univerzity v Plzni. Předmětem předkládaného př́ispěvku je seznámení širší odborné veřejnosti s problematikou výskytu hospodářských dvorů na středověkém a raně novověkém Chrudimsku.

\section{Metoda výzkumu}

Při výzkumu antropogenních reliktů v terénu využíváme především takové nedestruktivní archeologické metody, které je možné provádět opakovaně a které přinášejí výchozí, podstatné a doplňující informace pro studium středověkého osídlení v převážně zalesněném prostředí Železných hor. Nejvhodnější metoda, kterou lze jednoduše aplikovat na vymezeném polygonu, je srovnání výstupů leteckého laserového skenování (dále LLS) a vizuálního nedestruktivního archeologického průzkumu s následným detailním geodetickým zaměřením vybraných antropogenních reliktů pomocí totální měřičské stanice PENTAX V-227N a LEICA TS06plus 5" R500 přímo autory př́íspěvku. Pro sledované oblasti Chrudimska využíváme digitální modely reliéfu 5. generace (dále DMR5G) vytvořené metodou LLS (poskytuje Český úřad zeměměřický a katastrální). Kvalita zachycených, již interpretovaných archeologických reliktů na DMR5G není zcela vyhovující, ale větší rozměry jednotlivých antropogenních a přírodních reliktů je umožňují vcelku snadno lokalizovat, identifikovat a vizualizovat při použití programů např. ArcMap10 nebo SURFER. Dále jsou prováděny povrchové sběry, za určitých okolnosti doplněné o průzkum pomocí detektoru kovů. Všechny nálezy jsou zaměřeny pomocí GPS a při průzkumu za pomoci detektoru kovů a následné mikrosondáže jsou vždy archeologické situace zaměřeny pomocí totální stanice. Povrchové sběry jsou aplikovány nejen v blízkosti antropogenních reliktů, ale i v širším okolí, zejména na polích, v úvozech, ale i na březích částečně vypuštěných vodních nádrží (např. ZSV Ústupky - Musil 2007). Kvantita a kvalita získaných souborů artefaktů a ekofaktů je vždy závislá na nejrůznějších faktorech na dané lokalitě (např. př́rodní podmínky - sklon reliéfu, podloží; časová délka osídlení a jeho intenzita atd.). Proto všechny informace získané nedestruktivními metodami jsou popisovány podle formalizovaného deskriptivního systému v prostředí databázových aplikací a získaná data jsou následně porovnána s daty z jiných publikovaných lokalit. Destruktivní archeologický výzkum probíhal pouze v př́padech, které byly vyvolány stavební aktivitou investora (např. hrad Rabštejnek - Baierl-Musil-Netolický 2015). V neposlední řadě jsou predikce archeologických lokalit doplňovány o studium toponym v daném regionu, jako např. Zlatý potok, Zlatník, Zlatotok, Zlaté Prameny atd. Zejména kombinace studia místních a pomístních jmen s archeologickými metodami je velmi účinná a může napovědět mnohé o kontinuitě osídlení v daném regionu.

\section{Poznání vesnického osídlení regionu}

Jak bylo předestřeno v úvodní kapitole, poznání vývoje sídel a sídlištní struktury na Chrudimsku je velmi torzovité a opírá se především o starší práce Augusta Sedláčka (1900; 1900a), Antonína Profouse, Jana Svobody a Vladimíra Šmilauera (Profous 1947; 1949; 1951; ProfousSvoboda 1957; Svoboda-Šmilauer 1960) a Františka Roubíka (1959). Mezi dalšími pracemi věnovanými zejména výpovědi písemných pramenů zmiňme zejména rešerši prvních písemných zmínek o obcích na Chrudimsku (Šulc 2001, 189-246) a studie Jaroslava Teplého (1991; 1997; 1998; 1999; 2000; 2003; 2010). Vlastní struktuře, typům sídel a plužiny na Chrudimsku a v železnohorském regionu se věnoval zejména Luděk Štěpán, s důrazem na novověké období (Štěpán 1990; 1995; Štěpán et al. 2001; Štěpán-Růžičková-Šulc 2003).

Sledované území můžeme rozdělit na několik částí. Nížinatá severní část Chrudimska byla relativně hustě osídlena již v průběhu raného středověku. Ústředí představovalo centrum knížecí správy na hradišti v Chrudimi. V období 11.-12. století má venkovské osídlení charakter rozptýlený, s tzv. centrálními body, které představuje kostel, popř. panské sídlo (srov. Frolík-Sigl 1995). S analogickou situací se setkáváme na severozápadní hranici Železných hor např. v Pařížově, ZSV Stusyni (k. ú. Ronov nad Doubravou - Smetánka-Škabrada 1975, 262-266; 1977, 105-112; Sme- 
tánka 1987, 242) a ZSV Protivannech/Protivenicích (k. ú. Ronov nad Doubravou - Pehal 2003, 3-17; Smetánka 1987, 239) s dochovanými románskými kostely. Nutno poznamenat, že tato oblast souvisí s historickým Čáslavskem. Zejména Pařížov představuje zástupce archaické hromadné vsi (srov. Štěpán et al. 2001, 8, obr. 1:5). Předpokládáme, že úpatí Železných hor dosáhlo osídlení v průběhu středohradištního období (nálezy z Hradiště u Českých Lhotic), k zahuštování sídlištní sítě došlo později, pravděpodobně ve 12 . století. Změnu v podobě normativních sídlištních typů přineslo 13. století. Zatímco $\mathrm{v}$ dříve osídlených převážně odlesněných částech Chrudimska se setkáváme s vesnicemi návesního či ulicového typu, ve výše položených oblastech, kterých se dotkla vrcholně středověká kolonizace, vznikaly zejména lesní lánové a lesní návesní vsi. Z tohoto rámce vystupovala sídla vyššího typu s hospodářskou či tržní funkcí - městečka (např. Ronov nad Doubravou, Nasavrky, Bojanov, Raná), dále správní centra tvořená malým (např. tvrz Stoupec) či větším feudálním sídlem $\mathrm{s}$ přilehlým hospodářským zázemím v podobě poplužního dvora (Rabštejnek, Strádov), který se mohl postupem času rozrůst v městečko (např. Žumberk, Předhradí u Rychmburku, Podhradí u hradu Lichnice). Tuto strukturu doplňovaly tzv. dvorcové vsi s neuspořádaným půdorysem, které byly zakládány na mýtinách a pasekách a jejichž vznik je v našem zájmovém prostoru kladen do 16. století (srov. Štěpán 1995, 7; Štěpán et al. 2001, 9-10; Štěpán-Růžičková-Šulc 2003, 21). Nicméně v průběhu 14. a 15. století docházelo v důsledku klimatických změn, válečných událostí a dalších faktorů zejména ve vyšších polohách k redukci osídlení. Některé vsi a dvory zanikly jednorázově, jiné pustly postupně, popr. byly zredukovány na jedinou usedlost či samostatně stojící dvůr. $\mathrm{K}$ dosud nejméně poznaným sídlům pozdního středověku náleží samostatně stojící hospodářské dvory, postrádající zjevnou prostorovou vazbu $\mathrm{k}$ vesnickým jádrům. Lépe jsou známy hospodářské dvory vážící se $\mathrm{k}$ feudálnímu sídlu (např. Ostrov na Slánsku - Smetánka-Klápště-Richterová 1979; Hradečno - Novák-Vařeka 2014, 446-447; Rovný - Vařeka 2014; z našeho regionu viz níže) než tyto samostatně stojící dvory (např. Nevězeň - Vařeka et al. 2008, 117-126; Olešná - Vařeka 2014a). V našem příspěvku se pokusíme představit několik zástupců těchto sídel dokumentovaných v železnohorském prostoru (obr. 1).

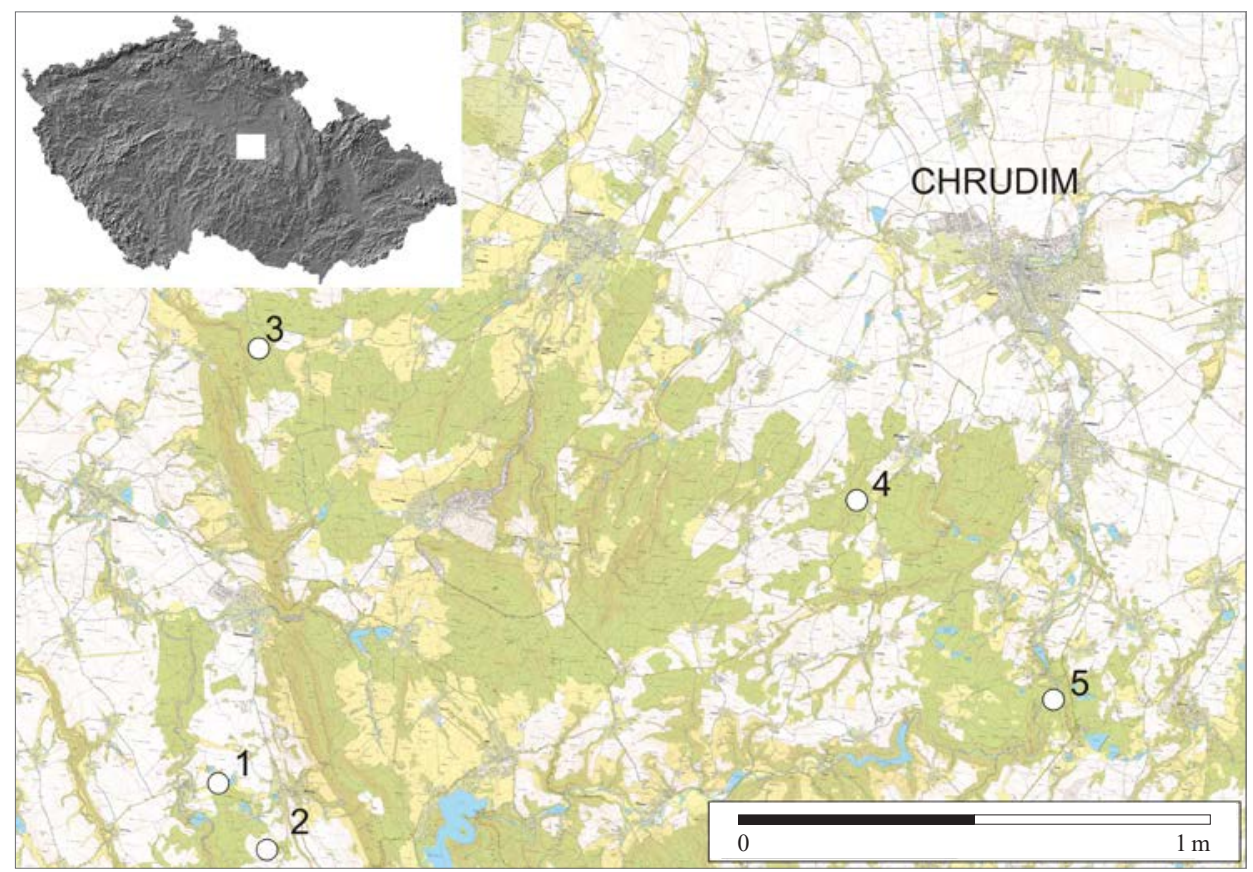

Obr. 1. Přehledná mapa lokalit zmíněných v textu: 1 - Stadla, 2 - Bolešov, 3 - Stoupec, 4 - Rabštejnek, 5 - Strádov. Abb. 1. Übersichtskarte der im Text genannten Fundstellen: 1 - Stadla, 2 - Bolešov, 3 - Stoupec, 4 - Rabštejnek, 5 - Strádov. 


\section{Podoba a typy hospodářských dvorů}

\subsection{Samostatně stojící hospodářský dvůr-Stadel (Stádla)}

Samostatně stojící dvůr zmiňovaný jako Stadel (Stádla či Štadl; obr. 2) se ve středověkých a novověkých písemných pramenech prakticky nevyskytuje. Jediná zmínka pochází z roku 1787 (Labut' 2004, 67). Nenalézáme ho však ani na starších mapových dílech (1. a 2. vojenské mapování, mapa stabilního katastru). Důvodem, proč nebyl v písemných pramenech doložen, je patrně sám název vycházející z německého spojení „bei den Stadlern“, tj. u stodol či kůlen (srov. Profous-Svoboda 1957, 156).

Zaniklý hospodářský dvůr se nalézá přibližně jeden kilometr východně od vsi Pařižova v katastrálním území Vestec u Běstviny. Relikt hospodářského dvora obdélného tvaru je ohraničen až 0,3 m vysokými pozůstatky kamenného zdiva a je orientován svou delší stranou téměř ve směru sever-jih (obr. 2, obj. 1). Maximální dochovaná délka areálu činí 66 m a maximální šířka je $19 \mathrm{~m}$. Na jižní straně došlo k narušení reliktů recentní těžbou. Na severozápadní straně se dochovaly pozůstatky po minimálně dvouprostorové stavbě (obj. 2). Přibližně do vzdálenosti dvou metrů od obj. 2 se nacházejí nepatrné stopy po dalších stavbách, které zřejmě k této dobře rozeznatelné stavbě v terénu přiléhaly. Nicméně tyto stopy nelze jednoznačně identifikovat a mohly vzniknout až později. Dochovaný relikt stavby (obj. 2) je minimálně 8,8 metrů dlouhý a 5,6 metrů široký. V jižní části objektu se dochovaly nevýrazné pozůstatky po kamenné př́ičce. Rozdíl vnitřní hrany objektu a prostoru dvora činí až $0,75 \mathrm{~m}$. V jihozápadní vnitřní části dvora (obj. 3) je patrný relikt cesty, nicméně ji nelze zcela ztotožnit se stáŕím vlastního dvora. Zaniklý hospodářský dvůr je umístěn na svahu, který má sklon od $5^{\circ} \mathrm{v}$ horní části do $10^{\circ} \mathrm{v}$ dolní části dvora.

Dále byly geodeticky zaměřeny čtyři antropogenní relikty vně ohraničené části hospodářského dvora. Dva objekty č. 4 a 5 můžeme s určitou dávkou opatrnosti interpretovat jako pozůstatky staveb, protože se vymykají svým charakterem drobným lomům umístěným v těsné blízkosti dvora. Objekt č. 4 je oválného konkávního charakteru o rozměrech $6,3 \times 2,9 \mathrm{~m}$ a hloubce $0,4 \mathrm{~m}$ s orientací delší strany v ose sever-jih. Objekt narušuje částečně ohrazení, nicméně nemusí jít o mladší zásah. Nelze vyloučit ani možnost, že jde o integrální součást dvora. Oproti tomu objekt č. 5 má tvar půlkruhu se špatně dochovanými stopami po kamenném zdivu. Jižní část objektu je silně narušena. Rozměry objektu činí $5 \times 4,5$ m. Dva větší objekty č. 6 a 7 můžeme interpretovat jako pozůstatky lomů pro těžbu kamene, které rovněž mohou souviset se zaniklým hospodářským dvorem.

\subsection{Zaniklá středověká ves redukovaná na hospodářský dvůr - Bolešov}

Zaniklá středověká ves Bolešov (k. ú. Spačice; obr. 3) představuje zástupce středověké vsi zredukované postupem času na pouhý poplužní dvůr (základní informace viz Musil-Netolický 2012). Relikty se nalézají na zalesněném jižně exponovaném svahu v trati Dubina v nadmořské výšce 346,0-348,0 m. Úvodem musíme konstatovat naprostý nedostatek písemných pramenů dovolujících poznat samé počátky ZSV Bolešova. Počátky osídlení oblasti je možné klást již do 12. století. Podle etymologického rozboru Antonína Profouse $(1947,112)$ se jméno Bolešov odvozuje od osobního jména Boleš nebo Boleša. V písemných pramenech z první poloviny 14 . století se setkáme se jménem Bolesud de Wesczie (RTV, 25 č. 129; RT II, 34 č. 170), bohužel nelze s jistotou říci, zda šlo o předchůdce držitele nedaleké tvrze a vesnice Vestce u Běstviny, který je připomínán k roku 1497 (AČ I, 351). Nelze také vyloučit, že Bolešov náležel k majetkům vilémovského kláštera.

První písemná zmínka o vsi Bolešov pochází až z roku 1491, kdy ji Jiřík a Václav z Rušinova prodali Mikuláši mladšímu Trčkovi z Lípy (RT II, 449; srov. Sedláček 1900a, 38). Jakým způsobem se Bolešov dostal do držení vladyků z Rušinova, nevíme. Pravděpodobně jej získal známý husitský hejtman Jan Hertvík z Rušinova. Podle Josefa Vítězslava Šimáka $(1933,327)$ roku 1508 náležel Bolešov k Vesci. Důležité je, že Bolešov a přilehlé okolí se stal součástí trčkovských držav v železnohorském regionu. Při prodeji panství v roce 1539 je Bolešov zmiňován pouze jako 
dvůr (Sedláček 1900a, 38 a 46), ale v letech 1544 (Profous 1947, 112), 1557 a 1586 jako ves (Sedláček 1900a, 46). Na sklonku 16. století zde tedy existovala ještě vesnice (patrně menší), ale již roku 1623 je zmiňován pouze dvůr. V dokumentu z roku 1654 již není o Bolešově žádná zmínka (Sedláček 1900a, 46). Je tedy zřejmé, že Bolešov zanikl v průběhu třicetileté války.

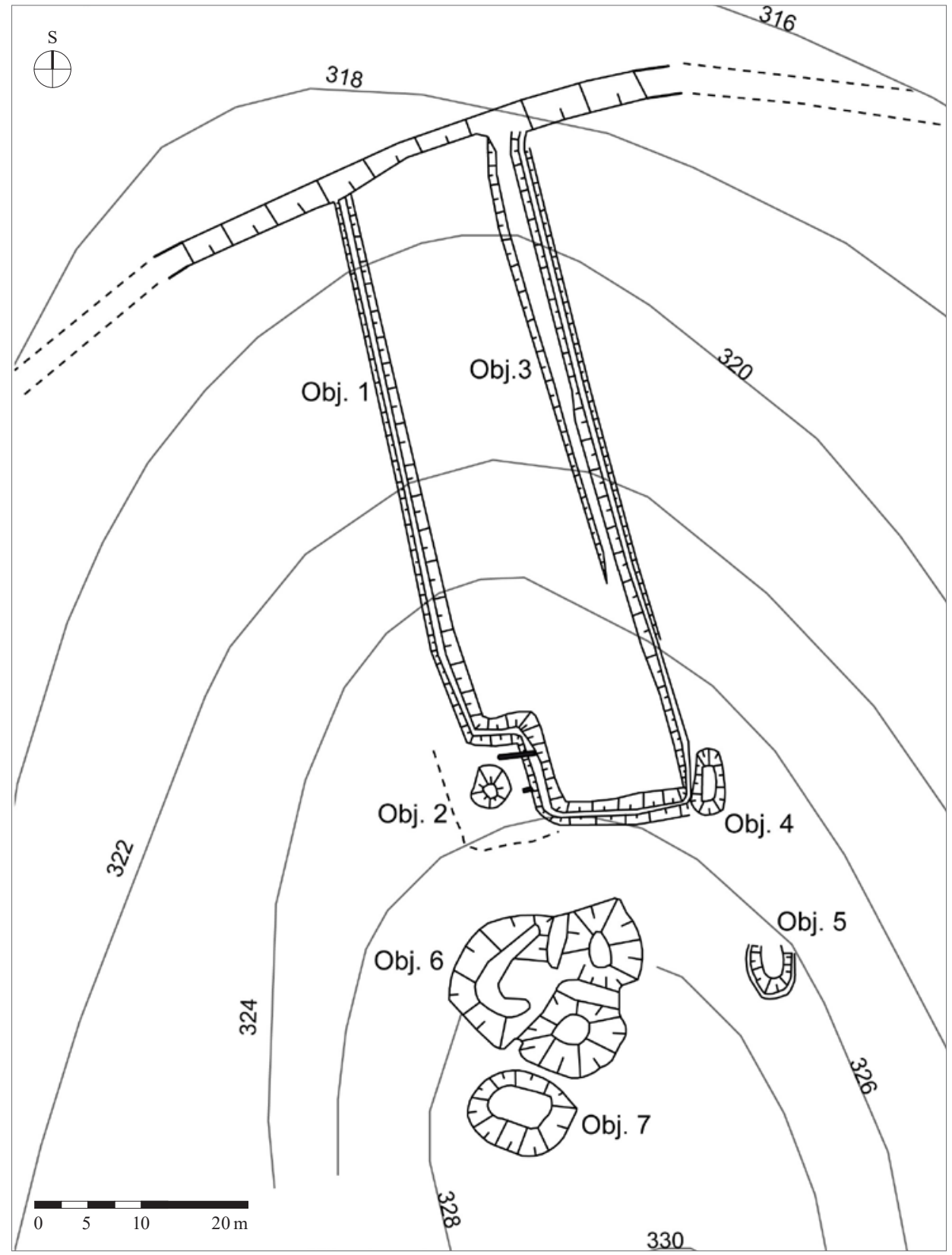

Obr. 2. Půdorysný plán reliktů zaniklého dvora Stadla, k. ú. Vestec u Běstviny. Vytvořeno pomocí programu ArcMap10. Mapové podklady poskytl ČÚZK.

Abb. 2. Grundrissplan der Relikte des wüsten Hofes Stadla, Katastergebiet Vestec u Běstviny. Erstellt mit der Software ArcMap10. Die Kartenvorlage wurde vom Tschechischen Amt für Landesvermessung und Kataster zur Verfügung gestellt. 
Shluk objektů konvexního a konkávního charakteru v severovýchodní části zkoumané lokality interpretujeme jako relikty obytných nebo hospodářských staveb. Objekty mají nejčastěji obdélný půdorys a jsou v určitém prostorovém vztahu k objektu 27 , který lze interpretovat jako dvorek. Do dvorku tak mohly být orientovány okapovou stranou relikty staveb - obj. 21, 22 a 23. Součástí konvexního objektu 22 byl i konkávní objekt 21, který lze interpretovat jako suterén nadzemní stavby (komory). Nelze vyloučit, že tyto tři objekty tvořily jednu stavbu přibližně o délce $35 \mathrm{~m}$ a šířce $7 \mathrm{~m}$.

Nápadné je uspořádání objektů 24, 14, 15 a část dochovaného objektu 16 kolem dvorku do tvaru písmene „L“. V tomto př́ípadě není zřejmé, zda šlo o jednu komplexní stavbu, nebo o samostatně stojící stavby orientované štítovou stranou směrem do dvorku.

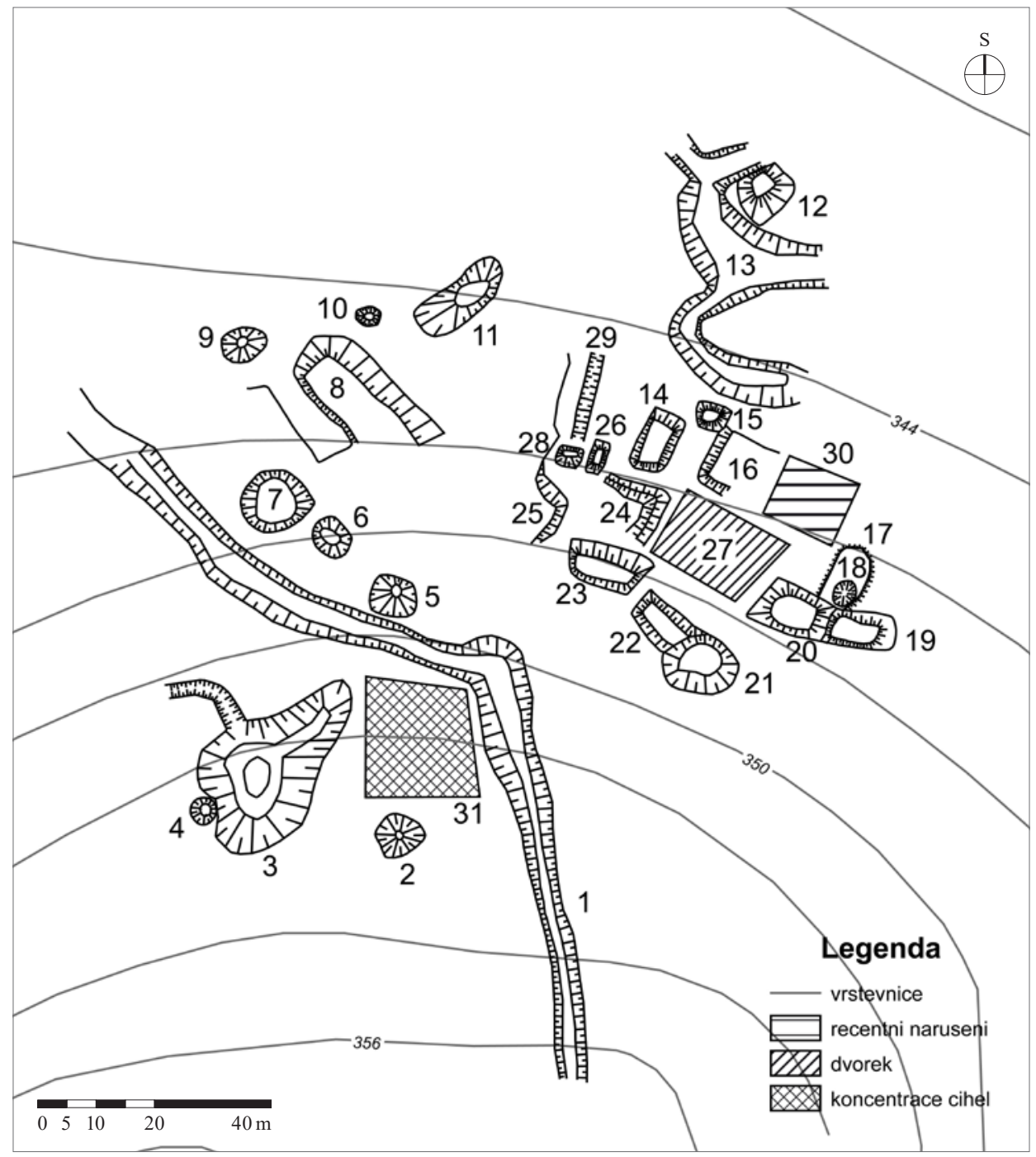

Obr. 3. Půdorysný plán reliktů ZSV Bolešov, k. ú. Spačice. Vytvořeno pomocí programu ArcMap10. Mapové podklady poskytl ČÚZK.

Abb. 3. Grundrissplan der Relikte der mittelalterlichen Dorfwüstung Bolešov, Katastergebiet Spačice. Erstellt mit der Software ArcMap10. Die Kartenvorlage wurde vom Tschechischen Amt für Landesvermessung und Kataster zur Verfügung gestellt. 
Objekty 26 a 28 jsou velmi špatně rozpoznatelné v terénu, a tak mohly být součástí objektů 24 a 14 nebo samostatně stojící a nelze ani vyloučit, že vznikly recentním zásahem.

Objekty 20 a 19 jsou přibližně stejně velké, nacházejí se v jedné linii a lze je interpretovat jako jednu stavbu. Problém nastává s objekty 17 a 18, které se projevují v terénu velmi špatně, a nelze je prokazatelně zařadit jako součást stavby. Další relikty staveb se nacházely patrně v prostoru označeném jako objekt 30 , kde byly zničeny těžbou dřeva.

Celý komplex výše zmíněných objektů nelze interpretovat jako zaniklou vesnici, ale jako jednu usedlost. Podle rozboru a interpretace zjištěných reliktů staveb je půdorys usedlosti kolem volného prostranství uprostřed téměř uzavřený.

Zajímavé terénní seskupení severně od usedlosti tvoří konvexní objekt 12, který interpretujeme jako relikt stavby, a konkávní nepravidelný liniový objekt 13.

Interpretačně sporná je situace $\mathrm{v}$ severozápadní části lokality, kde objekt 8 představuje nezvyklou terénní hranu. Především západní část objektu je tvořena destrukcí kamene, z čehož lze usuzovat na existenci stavby. V každém př́ípadě jde o antropogenní útvar.

Dva objekty lze označit zcela určitě jako komunikace. Objekt 1 je nezpochybnitelnou středověkou úvozovou cestou, která je využívána i v dnešní době k pěší turistice. Vede napříč sledovaným územím od jihu k severozápadu. Cesta probíhá nad interpretovanou usedlostí, ale nepodařilo se v terénu zachytit jejich vzájemné propojení. Druhý objekt 29 lze také interpretovat jako cestu, ta však sloužila spíše jako vnitřní komunikace uvnitř usedlosti. Třetí objekt 13 má velmi nepravidelný půdorys a lze ho interpretovat bud' jako relikt úvozové cesty, nebo jako vodní nádrž.

Prokazatelná studna (obj. 4) se nachází v jihovýchodní části zkoumaného území. Velmi dobrý stav zachování můžeme interpretovat tak, že ještě v nedávné době byla využívána, proto lze předpokládat i drobnější opravy. V současnosti je zaplněna listím, hrabankou a větvemi, a nelze tak spolehlivě odhadnout její hloubku. Vedle studny se rozkládá vodní nádrž (obj. 3). V její severozápadní části byla zjištěna odvodňovací strouha. Objekt má silně podmáčené dno a po delší část roku se v něm drží stojatá voda. Studna se nachází zhruba $90 \mathrm{~m}$ mimo plochu interpretované usedlosti, z čehož logicky vyplývá, že v její blízkosti se v minulosti musela nalézat další stavba či usedlost. Bohužel severním a západním směrem od studny se již rozkládají zemědělsky obdělávaná pole. V jejím bezprostředním sousedství na východní straně se nachází objekt 31, který tvoří značné množství cihel a prejzů v nepravidelných kumulacích mohylovitého charakteru. V tomto př́ípadě nemůžeme vyloučit možnost recentní skládky stavebního odpadu z nedalekých Spačic.

Na lokalitě se nachází další tři objekty 6,7 a 11, které mohly v minulosti sloužit jako menší vodní nádrže k hospodářským účelům. Problematický je objekt 13 (viz výše).

V prostoru zkoumané lokality byly zachyceny malé konkávní objekty s obvaly, které jsou pozůstatky reliktů po těžebních pracích. Na jihu zkoumané plochy to je objekt 2 a v severozápadní části lokality to jsou objekty 5,9 a 10 . Patrně i objekty 6 a 7 původně vznikly jako důsledek těžebních prací. Jednoznačně je nelze dávat do souvislosti se zaniklou usedlostí, a mohly tak vzniknout v nedávné minulosti. Určení suroviny, která byla předmětem těžby, je problematické. Na zkoumané lokalitě vystupují masivní skalní bloky na povrch, proto se přípovrchová těžba kamene zdá málo pravděpodobná.

Terénní relikty Bolešova se nalézají na ploše ca $150 \times 140$ m, vytvářejí se zde celkem čtyři výraznější koncentrace objektů, které jsou od sebe odděleny. Severovýchodní koncentrace tvořná objekty 12 a 13 navazuje na jižněji položenou skupinu objektů 14-30, a zahrnuje tak plochu o rozměrech ca $70 \times 95$ m. Východněji položená koncentrace objektů 5-11 respektuje hranici úvozové cesty (obj. 1), která ji po jižní straně obchází. Poslední koncentrace objektů 2-4 a 31 se nalézá na jihozápadní straně zkoumané lokality.

Doposud jedinou dokumentovanou lokalitou, která snese porovnání s objevenými terénními pozůstatky vsi/dvora Bolešova, je zaniklý poplužní dvůr Nevězeň na Rokycansku (Vařeka et al. 2008, 117-126). Lokalita interpretovaná jako dvůr sestává z celkem osmi objektů vytvářejících pravidelnou pravoúhlou koncentraci na ploše ca $20 \times 50 \mathrm{~m}$. Nad touto koncentrací se nalézá relikt vodní nádrže. 
Z poznatků získaných pouze povrchovým průzkumem lokality, bez archeologického odkryvu, nelze jednoznačně určit charakter a datování jednotlivých objektů. Obecně lze konstatovat, že Bolešov byl v průběhu své existence tvořen pouze dvěma až třemi usedlostmi, které se snad v průběhu 15. či 16. století transformovaly v poplužní dvůr.

\subsection{Panské sídlo nižšího typu s přilehlým hospodářským dvorem-tvrz Stoupec}

První písemnou zmínku o tvrzi Stoupec (obr. 4) představuje predikát Jana Chrast de Stupecz k roku 1394 (AČ XXXI, 34 č. 96). Osudy tvrze byly spojeny s dílem nedaleké vsi Hošt’alovice, které byly na konci 14 . století rozděleny mezi dva majitele. Beneš z Urbanic vlastnil roku 1384 pět kmetcích a jeden poplužní dvůr v Hoštalovicích, zbylý díl hošt’alovických kmetcích dvorů vlastnil spolu s poplužním dvorem u Stoupce Matěj zvaný Slaměnec (Nechvíle 1877, 67; Sedláček 1900a, 49). Z výše uvedeného ovšem explicitně nevyplývá, že Matěj vlastnil i tvrz. Matěj zvaný Slaměnec svůj díl v roce 1399 prodal Držkovi z Kratonos (Nechvíle 1877, 67). K roku 1417 je uváděna i ves (srov. Roubík 1959, 116). Tvrz je jako pustá uváděna roku 1486 (srov. Nechvíle 1877, 67). Roku 1492 je uváděn jako pustý i poplužní dvůr u tvrze (Sedláček 1900a, 49). Zánik tvrze a přilehlého dvora souvisí podle Augusta Sedláčka (1900a, 50) s tažením Matyáše Korvína k Vilémovu, nemůžeme ovšem vyloučit možnost, že tvrz s přilehlou vsí a poplužním dvorem byla vypálena již dř́ve $\mathrm{v}$ souvislosti s obléháním nedalekého hradu Lichnice v letech 1428-1429 (k tomu srov. Frolík-Musil 2013), přičemž ještě mohlo dojít k obnově hospodářského dvora. Ten s definitivní platností zanikl před rokem 1492, kdy je už uváděn jako pustý.

Celkem se podařilo identifikovat devět objektů - tvrz a pozůstatky hospodářského dvora - a vymezit těžební areál, ve kterém bylo identifikováno několik desítek útvarů spojených s exploatací nerostných surovin, patrně železné rudy (Musil-Netolický 2014b).

V těsné blízkosti tvrze se nachází v mírném svahu téměř obdélný objekt s výraznou konkávní částí. Objekt je delší stranou orientován ve směru sever-jih. Jeho rozměry se pohybují od 12,2 do 10,2 m. Nejvýraznější je konkávní část objektu, která dosahuje hloubky od horních partií až 1,3 m. Rozměry dna výrazné konkávní části objektu jsou mezi 5,6 a 5 m. Do této konkávní prostory směřuje úzká konkávní linie (na obr. 4 vyznačeno šipkou), kterou můžeme interpretovat jako vstupní šíji do zaniklého suterénu nadzemní budovy. Objekt 2 můžeme interpretovat jako zaniklý suterén se vstupní šíjí náležící nadzemní stavbě, patrně k tvrzi přiléhajícího poplužního dvora.

Velice dobře se dochovala vodní nádrž vzdálená jen 30 m jihozápadně od tvrze (obr. 3:3). Je umístěna v pramenné pánvi, odkud vyvěrá Mlýnský potok. Tato vodní nádrž má přibližně obdélný tvar se zaoblenými rohy a je orientována delší stranou ve směru východ-západ. Rozměry nádrže činí $22 \times 17$ m, výškový rozdíl mezi uměle nasypanou hrází vodní nádrže a současným dnem kolísá od 0,5 do 1,2 m, což je dáno terénní konfigurací. Při současném stavu dochování je celkem dobře patrné vyvýšení báze nádrže nad okolní terén. Přibližně ve středu jižní části nádrže bylo identifikováno velmi dobře zachovalé místo výpusti. August Sedláček (1900a, 49) toto místo na základě informace řídícího učitele Františka Horáka z Míčova označoval jako napajedlo pro dobytek. Vlastní zdroj pitné vody představovala studánka (obj. 4) napájená silným podpovrchovým pramenem. Studánka přibližně kruhového tvaru má průměr $0,8 \mathrm{~m}$ a hloubku $0,6 \mathrm{~m}$. Severní polovina studánky má v celé výšce $0,6 \mathrm{~m}$ dochováno kamenné roubení. Jižní odtoková část studánky je vysoká maximálně $0,2-0,3 \mathrm{~m}$. Její dno je rovněž vyskládáno z kamenů. Není bez zajímavosti, že studánku zmínil i August Sedláček (1900a, 49). Nepochybně představovala pro tvrz zdroj pitné vody.

Při výzkumu byly zaměřeny ještě další dva konkávní objekty nalézající se v mírném svahu v sousedství objektu 2 . Objekt 8 oválného tvaru o rozměrech $8,3 \times 5,8 \mathrm{~m}$ je poměrně dobře rozpoznatelný v terénu, je orientován delší stranou ve směru sever-jih a jeho severní část je zahloubená do svahu. Mohlo by jít o další zaniklý suterén nadzemního domu související s poplužním dvorem při tvrzi. S interpretačními obtížemi se setkáváme v případě nepravidelného objektu 9. Obdobně jako výše popisovaný objekt 8 je orientován delší stranou ve směru sever-jih. Součástí objektu je nevýrazná konvexní oválná část o rozměrech 5 × 3,6 m dosahující výšky 0,4 m. 


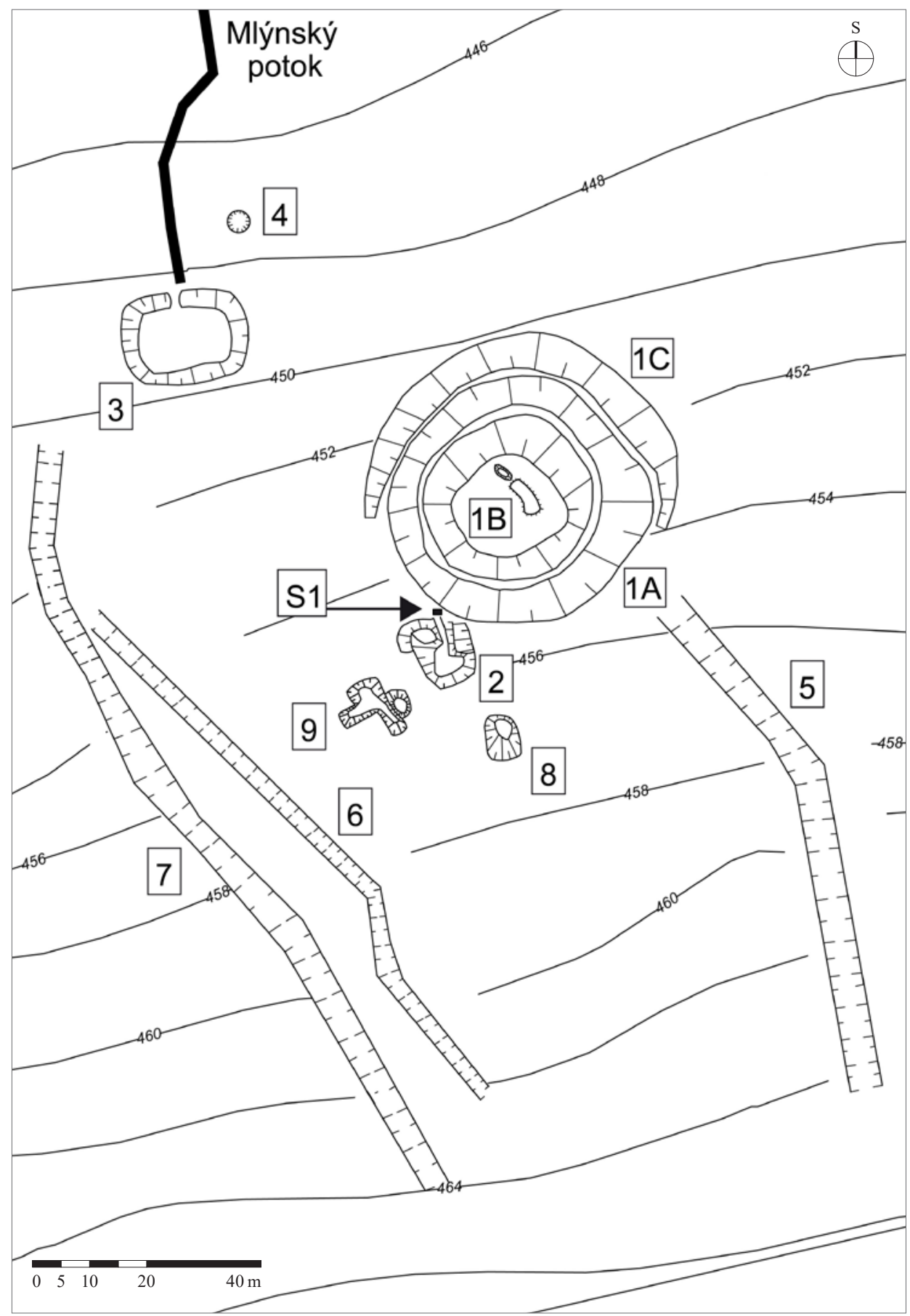

Obr. 4. Půdorysný plál reliktů zaniklé tvrze Stoupec, k. ú. Březinka u Hošt’alovic, a přilehlého hospodářského dvora. Vytvořeno pomocí programu ArcMap10. Mapové podklady poskytl ČÚZK.

Abb. 4. Grundrissplan der wüsten Feste Stoupec, Katastergebiet Březinka u Hošt’alovic, und des angrenzenden Wirtschaftshofes. Erstellt mit der Software ArcMap10. Die Kartenvorlage wurde vom Tschechischen Amt für Landesvermessung und Kataster zur Verfügung gestellt. 


\subsection{Panské sídlo vyššího typu s přilehlým hospodářským dvorem-hrad Rabštejnek}

Písemné prameny o hradu Rabštejnku (obr. 5) a jeho majitelích jsou velmi torzovité a málo vypovídají o stavebním vývoji hradu (výčet dostupných písemných pramenů Baierl-Musil-Netolický 2015). Někdy v průběhu první poloviny 14. století vznikl nevelký šlechtický hrad zmiňovaný v pramenech nejdříve jako Rabštejn. Později, ještě během středověku, se zřejmě díky jeho malé rozloze ujalo přízvisko Rabštejnek (např. 1446 a 1450). Jméno Rabštejn se udrželo po zániku hradu pro vesnici v sousedství, která je př́ímým pokračovatelem poplužního dvora před hradem (Teplý 1997, 39). První osoba, kterou by bylo možno s lokalitou spojovat, je poněkud záhadný „Mathiae de Rabstein“ zmiňovaný k roku 1360. Vzhledem $\mathrm{k}$ tomu, že jméno Rabštejn bylo v Čechách i na Moravě poměrně frekventované a ve zmínce není blíže specifikováno, je nutno tuto zmínku brát s rezervou (srov. Teplý 1997). Na přelomu 14. a 15. století byl majitelem panství Jetřich z Orle, připomínaný k roku 1404, který je tak prvním spolehlivým držitelem Rabštejnka. Patrně roku 1430 prodal Aleš z Orle hrad i s poplužním dvorem Hertvíkovi z Ostružna, který se ještě téhož roku píše „seděním na Rabštainku“ (Sedláček 1900, 144; AČ I, 415 č. 36; Desky dvorské III, 732 č. 19). První písemná zmínka dokládající existenci poplužního dvora pochází z 5. prosince 1450 (AČ III, 547 č. 569; RT II, 219), kdy Vilém z Ostružna prodal hrad s poplužním dvorem. V roce 1454 po smrti Jana zvaného Těchlovec připadl hrad jako odúmrt' na královskou komoru a Ladislav Pohrobek jej daroval Petru Kdulincovi z Ostroměře a Vilémovi z Dřele (AČ III, 555 č. 630). Od konce 15. století drželi hrad Šárovcové ze Šárova, kteří jej roku 1540 prodali městu Chrudimi. Chrudimští jej však nepodrželi dlouho, pro účast ve stavovském povstání roku 1547 přišla Chrudim i o toto panství a hrad se opět dostal do rukou královské komory. Ještě v listopadu téhož roku byl prodán a dostal se do držení pánů z Pernštejna. V roce 1548 hrad s pustým poplužním dvorem prodal Jan z Pernštejna Heřmanu Lhotskému ze Zásmuk (AČ XX, 524 č. 539). Nakonec jej roku 1575 koupil Bohuslav Mazanec z Frymburka. Roku 1585 se Rabštejnek poprvé připomíná jako pustý (Sedláček 1900, 146).

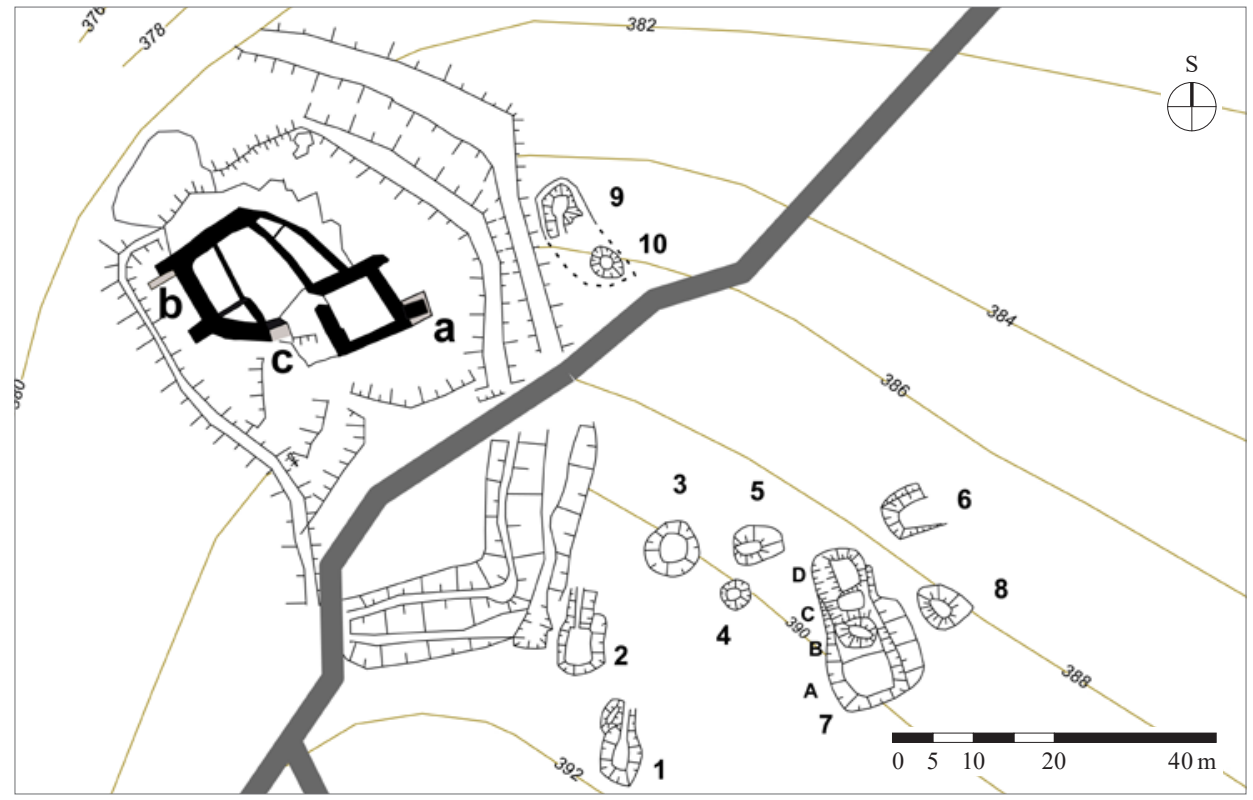

Obr. 5. Půdorysný plán hradu Rabštejnka s přilehlým poplužním dvorem, k. ú. Smrkový Týnec. Vytvořeno pomocí programu ArcMap10. Mapové podklady poskytl ČÚZK.

Abb. 5. Grundrissplan von Burg Rabštejnek mit angrenzendem Vorwerk, Katastergebiet Smrkový Týnec. Erstellt mit der Software ArcMap10. Die Kartenvorlage wurde vom Tschechischen Amt für Landesvermessung und Kataster zur Verfügung gestellt. 
Poplužní dvůr se nalézal mimo vlastní opevněný areál hradu na jeho jižní a jihovýchodní straně. Místy dochované lineární objekty naznačují, že byl obehnán obvodovou zdí, která byla přiložena k opevnění předhradí.

Celkem se podařilo identifikovat deset objektů, a vymezit tak hospodářské zázemí hradu, ve kterém bylo identifikováno několik pravidelných antropogenních útvarů spojených s hospodářskou činností hradu. Sklon reliéfu v místě interpretovaného poplužního dvora se pohybuje mezi $4^{\circ}$ a $6^{\circ}$. Popis a rozbor reliéfních tvarů vychází z publikovaného deskriptivního systému (Vařeka et al. 2006) a popis jejich vlastností byl upraven podle potřeb autorů článku.

Shluk objektů konvexního a konkávního charakteru jihovýchodně od tělesa valu předhradí interpretujeme jako relikty poplužního dvora. Tyto pozůstatky zaujímají obdélnou plochu o rozměrech $38 \times 54 \mathrm{~m}$. Plochu vymezují dvě řady reliktů jihovýchodní orientace s volnou plochou uprostřed o rozměrech $19 \times 43 \mathrm{~m}$, kterou lze interpretovat jako dvorek. V jižní části poplužního dvora nebyly identifikovány žádné objekty.

Největší objekt 7 můžeme interpretovat jako pozůstatek patrně obytné stavby, čemuž napovídá velikost reliktu $(19 \times 6,6-9 \mathrm{~m})$ a viditelné vícedílné členění. Relikt se minimálně dělí vizuálním průzkumem až na čtyři díly. V jižní části reliktu 7A je situován suterén (sklep), dále střední část 7B s vkleslinou 7C a mírně vyvýšená část na severní straně 7D. Hypoteticky lze tak uvažovat o minimálně trojdílném domě se suterénem a komorou na jižní straně. Síň a jizba se nacházely v severní části domu. V těsné blízkosti tohoto objektu byly zaznamenány dva objekty, jeden konkávní - obj. 6 a druhý konvexní - obj. 8. Oba můžeme interpretovat spíše jako hospodářské stavby. U objektu 8 nelze vyloučit, že jde o relikt recentního stáří. O obytných domech lze uvažovat i v př́ípadě objektů 1 a 2 umístěných naproti objektu 7. Objekty byly nejspíše vícedílné, ale bez archeologického terénního odkryvu nelze toto tvrzení ověřit. Nicméně lze konstatovat, že v př́ípadě objektů 1 a 2 mohly být další části stavby umístěny paralelně s př́kopem patrně severním směrem, orientované okapovou stranou domu jako v prrípadě objektu 7. Tuto hypotézu bude třeba dále ověřit. Samostatnou skupinu tvoří objekty 4 a 5 situované na východ od vodní nádrže (obj. 3), která byla pouze cisternou napájenou jen deštovou vodou. $\mathrm{V}$ př́ípadě objektu 5 se můžeme domnívat, že mohlo jít o jednodílný objekt hospodářského charakteru.

Z hlediska celkového uspořádání vytvářejí objekty téměř ze tří stran uzavřenou plochu s vnitřním volným prostranstvím $49 \times 19 \mathrm{~m}$. Na jižní straně nebyly zachyceny žádné relikty, což hypoteticky naznačuje, že se na tomto místě mohl nacházet vstup do areálu poplužního dvora.

Nejbližší publikovanou analogií ke zdejšímu hospodářskému dvoru je sídlištní komplex u hradu Řebřík (okr. Rokycany). Tento komplex u hradu byl tvořen hospodářským dvorem, vsí s plužinou a dodnes stojícím kostelem. Antropogenní relikty doplňují zaniklé úseky úvozových cest, lom, haltýř a rybník (Durdík 1977; Durdík-Frolík 1982). Z vesnického prostředí známe hospodářské dvory lépe (srov. obecně Chotěbor-Smetánka 1985). Podobný poplužní dvůr v blízkosti tvrze byl identifikován pomocí nedestruktivních archeologických metod v místě ZSV Rovný (okr. Rokycany). Dvůr sestávající z celkem pěti antropogenních reliktů zahrnoval plochu $46 \times 52 \mathrm{~m}$ (Vařeka 2014). V rámci zaměřování současného stavu zříceniny hradu byly také geodeticky zaměřeny dva zahloubené relikty, které patrně byly součástí jedné nadzemní stavby umístěné v severovýchodním cípu hradního areálu v sousedství př́ikopu těsně nad strmým svahem na skalním suku. Nejlépe je dochován téměř obdélný objekt 9 o rozměrech $6,5 \times 5,5 \mathrm{~m}$. Dochovaná hloubka objektu se pohybuje v rozmezí od 0,3 do $0,7 \mathrm{~m}$. Menší téměř kruhový objekt 10 o průměru 3,5 a 4,5 m dosahuje hloubky $0,5 \mathrm{~m}$. Minimální vzdálenost mezi objekty je pouze $3 \mathrm{~m}$ a prostor mezi nimi je mírně vyvýšen nad ostatním terénem. Tyto objekty však v současnosti nelze jednoznačně přiřadit do stejného období jako poplužní dvůr. Nicméně obdobné zahloubené antropogenní relikty umístěné v těsné blízkosti fortifikace se vyskytují v daném regionu např. u tvrze Stoupec (srov. výše; Musil-Netolický 2014b). 


\subsection{Panské sídlo vyššího typu s přilehlým dvorem a mlýnem - hrad Strádov}

Poprvé se jméno hradu Strádov (obr. 6) objevuje v predikátu Jaroše Lacemboka z Chlumu a ze Strádova v roce 1374 (SA I, 106-107 č. 181). V roce 1438 je zmiňován Jan ze Strádova, který hrad spolu se dvorem v Drahoticích, s vesnicemi Nasavrky, Trojovicemi, Přestavlky, Zájezdcem, Javorným, Ochozem, Obořicí, Peklem a Výsonínem zastavil za 600 kop grošủ Aleši z Bítovan, Benešovi z Křivého a Janovi z Lipky (AČ III, 520 č. 390). Záhy po tomto datu hrad zpustl, předpokládá se jeho poškození za husitských válek. Zůstává ovšem otázkou, zda tu svou roli nehrálo přistoupení Aleše z Bítovan ke čtyřem spojeným krajským landfrýdům v roce 1440 (Sedláček 1900, 170). Ještě roku 1444, po smrti Jana ze Strádova, je hrad Janovými věřiteli spolu s výše uvedenými statky prodán Janu Slonovi ze Seslavic za 400 kop grošů (AČ III, 520 č. 390). Srovnáme-li hodnotu panství v roce 1438 (600 kop) a v roce 1444 (400 kop), je patrný úbytek hodnoty panství o 200 kop grošů, což svědčí o jeho zpustnutí. Jako pustý se hrad uvádí k roku 1457 (,... munitio diruta Stradow...“) a roku 1459 je pak uváděn výslovně jako zbořený (výčet dostupných pramenů viz Musil-Netolický 2015c).

První koncentrace objektů zaujímající ústřední hradní jádro a předhradí je umístěna centrálně na skalním výběžku v nadmořské výšce 360-363 m, ze kterého lze kontrolovat veškeré komponenty sídelního areálu hradu, ale i vzdálené okolí, zejména tok Chrudimky. Nejmenší samostatná jednotka sídelního areálu je tvořena reliktem dvojdílné stavby (obj. 2) situované v těžce prŕístupném terénu na terase pod strmými svahy. Patrně právě díky umístění stranou od „prrístupnějších“ reliktů se dochovala dvojdílná stavba s vodní nádrží ve velmi dobrém stavu.

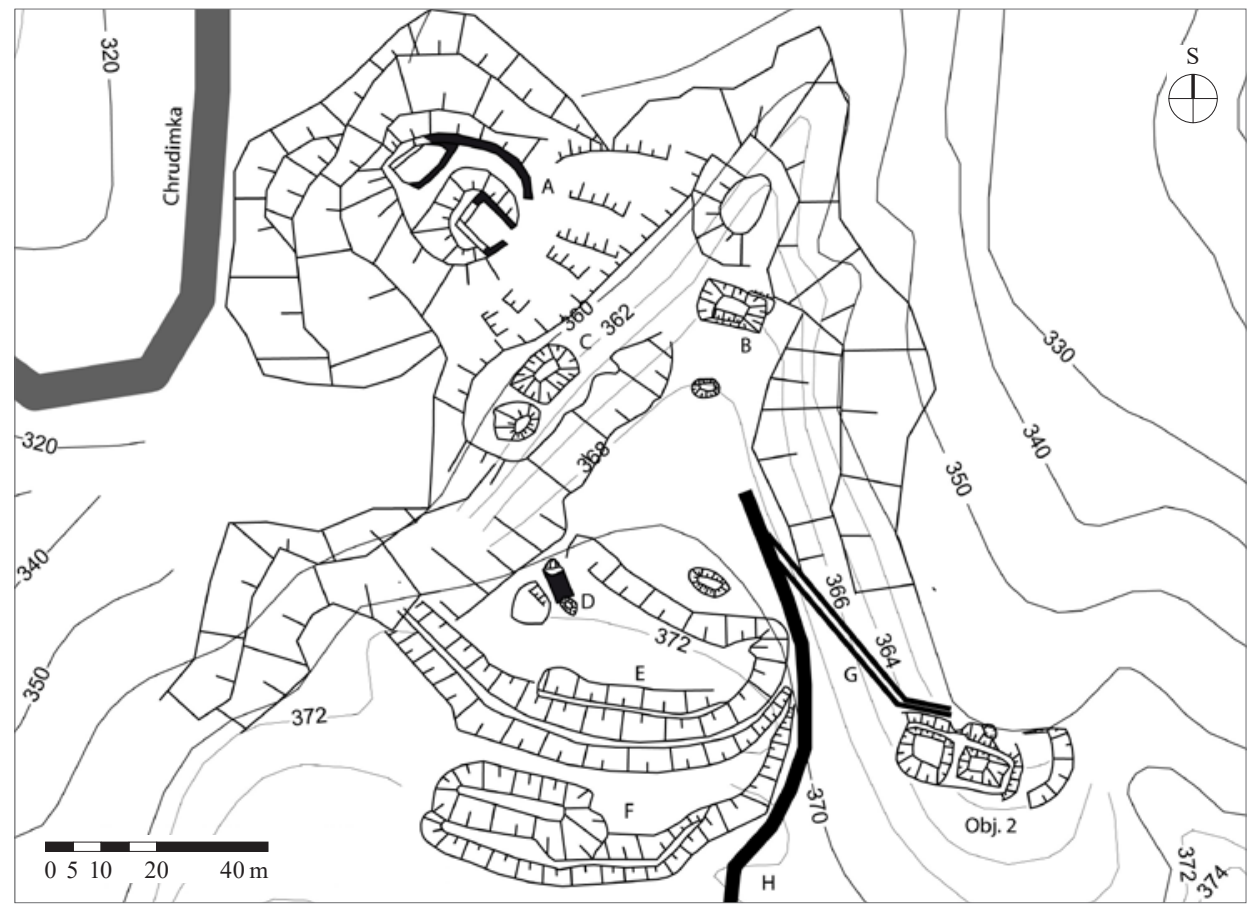

Obr. 6. Půdorysný plán hradu Strádova (k. ú. Ochoz u Navasavrk) s hospodářským zázemím na předhradí (koncentrace A a B). A - hradní jádro, B - pozůstatky suterénu, C - cisterna vylámaná do skály, D - zděný sklep s valenou klenbou, E - zděné opevnění předhradí, F - nedokončený příkop s valem, G - přístupová komunikace k obj. 2, H - průběh hradní komunikace. Vytvořeno v programu ArcMap10.

Abb. 6. Grundrissplan von Burg Strádov (Katastergebiet Ochoz u Navasavrk) mit wirtschaftlichem Hinterland und Vorburg (Konzentration A und B). A - Kernburg, B - Überreste des Souterrains, C - in den Felsen gehauene Zisterne, D-gemauerter Keller mit Tonnengewölbe, E-Mauerbefestigung der Vorburg, F - nicht fertig gestellter Graben mit Wall, G-Zugangsweg zu Objekt 2, H - Verlauf der Burgwege. Erstellt mit der Software ArcMap10. 


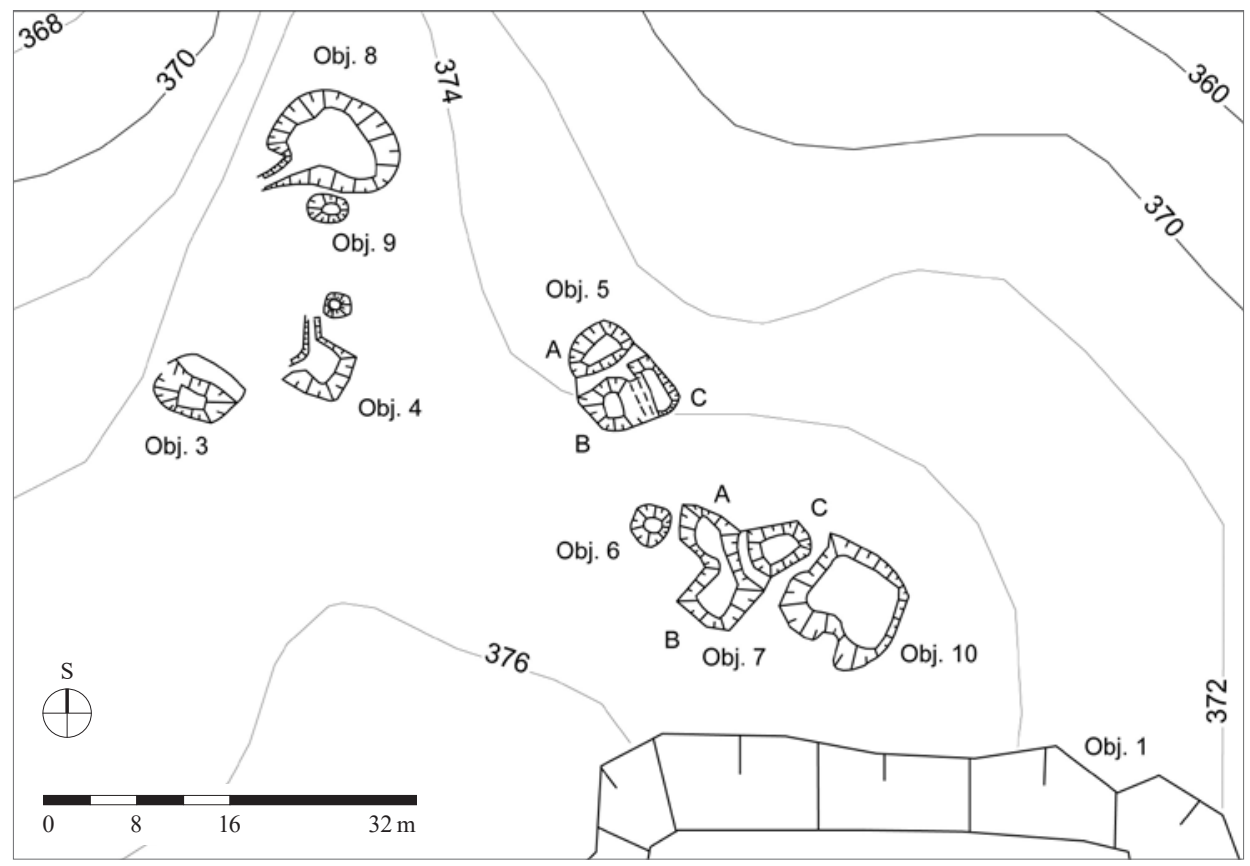

Obr. 7. Hrad Strádov, okr. Chrudim. Zaměření objektů v jihovýchodním předpolí hradu (koncentrace C). Vytvořeno v programu ArcMap10.

Abb. 7. Burg Strádov, Bezirk Chrudim. Vermessung der Objekte im südöstlichen Vorfeld der Burg (Konzentration C). Erstellt mit der Software ArcMap10.

Přístup do objektu byl zřejmě přímo z předhradí před prvním příkopem a valem. Podle Miroslavy Cejpové $(2003,39)$ šlo o soustavu tří nádrží na vodu. S touto interpretací se nelze ztotožnit, ačkoliv poslední částí objektu vodní nádrž skutečně byla. Záměrné umístění stavby na vodním zdroji (prameništi) a relikt menší vodní nádrže umožňuje interpretovat objekt jako hospodářskou stavbu, která zároveň sloužila jako rezervoár pramenité pitné vody pro hrad. Umístění stavby v terénu však vylučuje její obranu z východní i jižní strany.

Jako jistou ochranu objektu 2 lze označit pozůstatky staveb, které byly identifikovány na plošině (375-376 m n. m. - koncentrace C) umístěné východně od hradu. Nejlépe zachovaný a interpretovatelný ze všech objektů je relikt sklepa nebo suterénu patrně nadzemního domu (obj. 4). V objektu na západní straně se dochovaly viditelné kamenné relikty zdí se severně vybíhající vstupní šijí. Ostatní objekty interpretované jako relikty staveb (obj. 3 a 5) neměly dochované relikty kamenných stěn a ani jasně rozpoznatelné vstupní šíje. Pouze v případě objektů 3 a 7 se na hranách stěn zachovaly patrně relikty kamenné podezdívky. Dva objekty (obj. 8 a 10) lze identifikovat jako mělké povrchové lomy na kámen. Všechny objekty včetně dokladů povrchové těžby jsou orientovány stejným, tj. severozápadním směrem. Podobně i vstupní šíje jsou obráceny svým ústím směrem ke hradu. Je možné, že představují doklad v písemných pramenech nezachyceného hospodářského dvora u hradu. Podobné umístění mimo hrazenou plochu sledujeme např. u dvora při hradě Rabštejnku (Baierl-Musil-Netolický 2015, 23-51) či u tvrze Stoupec (Musil-Netolický 2014b, 148-180). Zároveň nevylučujeme možnost, že dvůr byl vůči okolí uzavřen alespoň plotem, po kterém se nedochovaly výraznější terénní stopy. Vyjma toho je na ploše (koncentrace C) viditelné značné množství drobných konkávních nebo konvexních antropogenních reliktů, které mohly vzniknout při těžbě kamene a písku až v 19. století. Přičemž mohlo být zničeno množství stř̌edověkých situací. Vlastní předhradí, vymezené na severní straně již zmiňovaným šíjovým př́ikopem, na západní a východní straně prudkými srázy, bylo na jihovýchodní straně odděleno několika fortifikačními liniemi sestávajícími ze zděné hradby, 
prŕíkopů a valů. Poměrně rozsáhlá plocha předhradí (ca $4928 \mathrm{~m}^{2}$ ) byla členěna na tři výškové stupně. Na nejnižším stupni v přímém sousedství jádra hradu se nalézají částečně zasuté zbytky do skály vytesané cisterny (k tomu srov. Sedláček 1900, 159; Svoboda 1985, 120; Cejpová 2003, 37, pozn. 2 a 3) a několik pozůstatků po stavbách lehčí konstrukce. Na středním, plošně nejrozsáhlejším stupni se nalézala zděná budova s částečně dochovaným valeně klenutým sklepem a další zástavba spíše lehčího charakteru. Nejvyšší, tř̌etí stupeň uzavírala kamenná hradba, jejíž pozůstatky jsou nejlépe patrné na východní straně. Zde zřejmě musel být branský objekt, do nějž ústila hlavní komunikace. Před zděnou hradbou se nalézal druhý př́íkop a malá plošina, před níž se dochovaly zbytky nedokončeného příkopu a sypaného valu. Hlavní přístupová komunikace probíhala podél východní hrany ostrožny, patrně po dřevěné mostovce překračovala z nejnižšího stupně předhradí po dřevěné konstrukci šíjový př́íkop a ústila v prostoru hradního jádra. $\mathrm{Na}$ východní straně v prostoru druhého stupně předhradí jsme registrovali odbočku z komunikace směřující do poloviny východního svahu, kde jsme objevili torzo zděné architektury se zdrojem pitné vody (obj. 2). Těchto antropogenních reliktů si povšimla již M. Cejpová a interpretovala je jako nádrže na vodu (Cejpová 2003, 39). Jelikož považovala cestu za novověkou (vzhledem k údajné superpozici s opevněním předhradí), domnívala se pravděpodobně, že i tyto relikty nebudou středověkého stárí, a patrně proto je do plánu hradu nezanesla (srov. Cejpová 2003, obr. 1).

Poslední součást hospodářského zázemí hradu představoval mlýn na spodní vodu umístěný 400 m severně od hradu v meandru řeky Chrudimky. Náhon k mlýnu byl umístěn východně od objektu 11A a ústil do řeky pod reliktem kamenného mostu. Od mostu kolem mlýna je dobře znatelná úvozová cesta, která byla až později nahrazena současnou lesní cestou.

\section{Diskuse a závěr}

Jak jsme konstatovali v úvodní kapitole, základní sídlištní jednotku oblasti představovaly vesnice, které $\mathrm{v}$ některých př́ípadech nahradila tržní centra větší pozemkové domény v podobě městeček (např. Ronov nad Doubravou, Bojanov, Nasavrky). Paralelně s tímto modelem musíme počítat $\mathrm{s}$ panským sídlem $\mathrm{s}$ přilehlým hospodářským zázemím (ke vztahu dvora k panskému sídlu srov. Plaček 1987, zejména 346-349). V zalesněném prostoru Železných hor se setkáváme se dvěma zásadními typy. První představuje spojení tvrze s hospodářským dvorem, které je charakterističtější spíše pro nížinatou část Chrudimska. Výjimku z tohoto pravidla pozorujeme u tvrze Stoupec, s přilehlým hospodářským dvorem a vsí. Tento fakt je však možno vysvětlit potřebou kontroly exploatace železné rudy. Druhým, častějším případem vazby panského sídla na hospodářské zázemí jsou hrady s přilehlým hospodářským zázemím v podobě poplužního dvora (Rabštejnek) či dalších objektů (např. mlýn pod hradem Strádov). Takový dvůr přiléhající k hradní stavbě se mohl za příznivé politicko-ekonomické situace rozrůst do podoby městečka (např. Žumberk, Předhradí u Rychmburku, Podhradí u hradu Lichnice). Uvedenou strukturu doplňovaly tzv. dvorcové vsi s neuspořádaným půdorysem, které byly zakládány na mýtinách a pasekách a jejichž vznik je v našem zájmovém prostoru kladen do 16. století (srov. Štěpán 1995, 7; Štěpán et al. 2001, 9-10; Štěpán-Růžičková-Šulc 2003, 21). Nicméně v průběhu 14. a 15. století docházelo v důsledku klimatických změn, válečných událostí a dalších faktorů zejména ve vyšších polohách k redukci osídlení. Některé vsi a dvory zanikly jednorázově, jiné pustly postupně, popř. byly zredukovány na jedinou usedlost či samostatně stojící dvůr.

Shrneme-li si naše poznatky, poukázali jsme na několika dobře dokumentovaných př́ikladech z železnohorského regionu na tyto základní typy hospodářských dvorů:

1. samostatně stojící hospodářské dvory zahuštující řidší sídlištní strukturu,

2. samostatně stojící hospodářské dvory vzniklé redukcí větší vsi,

3. hospodářské dvory vázané na feudální sídlo: a) na tvrz; b) na hrad (z této posledně zmiňované varianty se mohlo vyvinout i poddanské městečko). 
Tato studie je dílčím výsledkem projektu Studentské grantové soutěže Západočeské univerzity v Plzni SGS-2016-053 „Hospodářské zázemí a přírodní prostř̌edí zaniklých středověkých a novověkých vesnických sídel - 2. etapa“.

\section{Prameny a literatura}

AČ I: Archiv český čili staré pjsemné památky české i morawské z archivůw domácjch i cizjch I (Palacký, F., ed.). Praha 1840.

AČ III: Archiv český čili staré písemné památky české i morawské z archivůw domácích i cizích III (Palacký, F., ed.). Praha 1844.

AČ XXXI: Archiv český čili staré písemné památky české i moravské. První kniha provolací desk dvorských z let 1380 až 1394. Díl XXXI (Friedrich, G., ed.). Praha 1921.

AČ XXXV: Archiv český čili staré písemné památky české i moravské z archivů domácích i cizích XXXV (Friedrich, G., ed.). Praha 1935.

BAIERL, P.-MUSIL, P.-NETOLICKÝ, P., 2015: Současný stav a obnova zříceniny hradu Rabštejnka (k. ú. Smrkový Týnec) - Gegenwärtiger Zustand und Restaurierung der Ruine von Burg Rabštejnek (Katastralgebiet Smrkový Týnec), AH 40, 23-51.

CEJPOVÁ, M., 2003: Hrad Strádov - Burg Strádov, Dějiny staveb. Sborník příspěvků z konference Dějiny staveb 2002, 35-40. Plzeň.

DESKY DVORSKÉ III: Desky dvorské království českého III. Druhá kniha provolávací z let 1411-1448 (Friedrich, G., ed.). Praha 1941.

FROLÍK, J., 1989: Archeologické památky Hlinecka a Chrastecka. Hlinsko.

- 1989a: Nález raněstředověké keramiky ze Sečské přehrady na Chrudimsku, Zpravodaj Krajského muzea východních Čech XVI/1, 70-77.

FROLÍK, J.-MUSIL, J., 2011: Hrochův Týnec v proměnách staletí. Pravěk a středověk. Hrochův Týnec.

- 2012: Záchranné archeologické výzkumy v Předhradí (okr. Chrudim) v roce 2012. Příspěvek k poznání opevnění tzv. Městečka, Chrudimský vlastivědný sborník 16, 185-206.

FROLÍK, J.-SIGL, J., 1995: Chrudimsko v raném středověku. Hradec Králové.

- 1998: Chrudim v pravěku a středověku. Obrázky z každodenního života. Chrudim.

LABUŤ, J., 2004: Třemošnice od Lichtenburků k současnosti. Třemošnice nad Doubravou.

MENCLOVÁ, D., 1972: České hrady. Díl první. Praha.

MUSIL, J., 2007: Neznámá zaniklá střredověká vesnice pod Sečskou přehradou (k. ú. Seč a Hoješín, okr. Chrudim), Zpravodaj muzea v Hradci Králové 33, 199-219.

- 2011: Nové středověké a raně novověké nálezy z Trhové Kamenice (okr. Chrudim, Pardubický kraj), Východočeský sborník historický 19, 59-104.

- 2011a: Př́íspěvek archeologie k dějinám Trhové Kamenice, okr. Chrudim, ASČ 15, 969-988.

MUSIL, J.-NETOLICKÝ, P., 2012: Zaniklá středověká a raně novověká ves Bolešov v k. ú. Spačice, okres Chrudim, Pardubický kraj, Východočeský sborník historický 22, 73-114.

- 2013: Studium dynamiky středověkých sídelních struktur v tzv. bojanovském újezdu (Železné hory, okres Chrudim), REA - Živá archeologie 15, 32-37.

- 2014: Současný stav a perspektivy výzkumu antropogenních pozůstatků sídelních, výrobních a těžebních areálů v prostoru Železných hor, Archeologie východních Čech 5 (2013), 227-239.

- 2014a: Pozůstatky rýžování zlata v tzv. bojanovském újezdu (okres Chrudim) - Goldwäschereirelikte im sog. Bojanov-Sprengel (Bezirk Chrudim), AH 39, 637-655.

- 2014b: Tvrziště Stoupec a jeho hospodářské zázemí. Výsledky povrchového průzkumu na k. ú. Březinka u Hoštalovic (okr. Chrudim), Archeologie východních Čech 5 (2013), 148-180.

- 2014c: Dokumentace reliktů středověké těžby kovů v Železných horách, REA - Živá archeologie 16, 32-38.

- 2015: Výsledky povrchového průzkumu Železných hor v roce 2014, Výzkumy v Čechách 2014. Zprávy ČAS - Supplément 97, 52.

- 2015a: Rýžování zlata na Chrudimsku, REA - Živá archeologie 17, 60.

- 2015b: Dokumentace reliktů předhradí hradu Strádova (okres Chrudim) - Dokumentation der Relikte der Vorburg von der Burgruine Strádov (Bezirk Chrudim), AH 40, 457-473

- v tisku: Nové archeologické nálezy z tzv. bojanovského újezdu (Železné hory, okres Chrudim), Praehistorica.

NECHVÍLE, J., 1874-1877: Bývalé panství Podhořany na Čáslavsku, Památky archaeologické a místopisné $\mathrm{X}, 56-68$. 
NOVÁK, D.-VAŘEKA, P., 2014: Tvrze na Kladensku - Festen in der Region Kladno, AH 39, $439-471$.

PEHAL, Z., 2003: Keramika 13. století od kostela svatého Kříže nedaleko Ronova nad Doubravou (okr. Chrudim), Chrudimský vlastivědný sborník 7, 3-17.

PLAČEK, M., 1987: Ves a dvůr Holoubek. Ke vztahu dvora a panského sídla ve středověku - Dorf und Hof Holoubek. Zur Frage der Beziehung zwischen Hof und Herrensitz, AH 12, 345-354.

PROFOUS, A., 1947: Místní jména v Čechách. Jejich vznik, původní význam a změny. Díl I. A-H. Praha.

- 1949: Místní jména v Čechách. Jejich vznik, původní význam a změny. Díl II. CH-L. Praha.

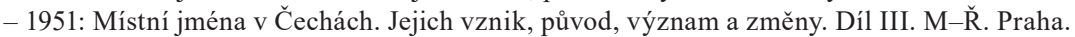

PROFOUS, A.-SVOBODA, J., 1957: Místní jména v Čechách. Jejich vznik, původní význam a změny. Díl IV. S-Ž. Praha.

ROUBÍK, F., 1959: Soupis a mapa zaniklých osad v Čechách. Praha.

RT II: Reliquiae tabularum terrae regni bohemiae anno MDXLI igne consumptarum II. (Emler, J., ed.). Pragae 1872 .

RTV: Reliquiae tabularum terrae citationum vetustissimae (Emler, J.-Dvorská, F., edd.). Pragae 1868.

SA I: Soudní akta konsistoře Pražské I. (Acta judiciaria consistorii Pragensis) (Tandra, F., ed.). Praha 1893. SEDLÁČEK, A., 1900: Hrady, zámky a tvrze království Českého. Díl I. Praha.

- 1900a: Hrady, zámky a tvrze království Českého. Díl XII. Praha.

ŠIMÁK, J. V., 1933: Místopisné drobnosti, ČČH XXXIX, 327-341.

SMETÁNKA, Z., 1987: Hledání zmizelého věku. Praha.

SMETÁNKA, Z.-KLÁPŠTĚ, J.-RICHTEROVÁ, J., 1979: Geodeticko-topografický průzkum zaniklé středověké vsi Ostrov (k. o. Jedomělice) - Geodetical-topographical survey of deserted medieval village Ostrov, AR XXI, 420-430.

SMETÁNKA, Z.-ŠKABRADA, J., 1975: Nové poznatky o raně středověké architektuře na Čáslavsku, Umění XXIII, 262-266.

- 1977: K počátkům městečka Ronova nad Doubravou. In: Středověká archeologie a studium počátků měst (Richter, M., ed.), 105-112. Praha.

SVOBODA, L., 1985: Ochoz, hrad Strádov, Výzkum v Čechách 1982-1983, 120.

SVOBODA, J.-ŠMILAUER, V., 1960: Místní jména v Čechách. Jejich vznik, původ, význam a změny. Díl V. Dodatky. Praha.

ŠTĚPÁN, L., 1990: Lidové stavitelství v plánech a mapách východočeských archivů. I. Technické a společenské stavby. Pardubice - Ústí nad Labem.

- 1995: Lidové stavitelství v plánech a mapách východočeských archivů II. Sídla, domy a zemědělské stavby. Zámrsk.

ŠTĚPÁN, L.-RU゚ŽIČKOVÁ, R.-ŠULC, I., 2003: Chrudimsko. Ztracené i zachráněné poklady. Chrudim.

ŠTĚPÁN, L. et al., 2001: Chrudimsko. Utváření venkovských sídel. Chrudim.

ŠULC, I., 2001: Soupis prvních písemných zmínek k sídlům okresu Chrudim, Chrudimský vlastivědný sborník 6, 189-246.

TEPLÝ, J., 1991: Heřmanoměstecký statek koncem 14. století, Východočeský sborník historický 1, $13-48$.

- 1997: Feudální pozemková držba v předhusitském Chrudimsku. Pardubice.

- 1998: K lokalisaci některých osad statku hradu Rychmburk v roce 1392, Scientific papers of the University of Pardubice, Series C 4, 129-170.

- 1999: Osady statku hradu Rychmburk v deskovém vkladu z roku 1392, Scientific papers of the University of Pardubice, Series C 5, 93-113.

- 2000: Osady statku hradu Rychmburk v deskovém vkladu z roku 1392 (II), Scientific papers of the University of Pardubice, Series C 6, 127-152.

- 2003: Také vesnici Hlínu, jíž se říká u kostela... a ochoz lesa blízko téže vesnice až k řece Rokytné a až k lesu Vrbatovu a Zdeslavovu. Lesní trati a opevněná sídla na okraji zeměpanského hvozdu, Scientific papers of the University of Pardubice, Series C 9, 5-32.

- 2010: Bojanovský újezd neboli districtus boyanouyensis v letech 1329-1419, Východočeský sborník historický $18,93-150$.

VAŘEKA, P., 2014: Zaniklá středověká a časně novověká ves Rovný na Zbirožsku (okr. Rokycany), Archeologie západních Čech 7, 131-143.

- 2014a: Zaniklý pozdně středověký dvůr u Olešné na Rokycansku, Archeologie západních Čech 8, 134-143.

VAŘEKA, P. et al., 2006: Archeologie zaniklých středověkých vesnic na Rokycansku I. Plzeň.

VAŘEKA, P., et al., 2008: Archeologie zaniklých středověkých vesnic na Rokycansku II. Plzeň.

VORÁČEK, E. et al., 2010: Luže v dějinách. Díl 1. Luže.

VORÁČEK, E. et al., 2011: Dějiny Skutče. Skuteč. 


\section{Zusammenfassung}

\section{Zwischen Dorf und Herrschaftssitz. Mittelalterliche Höfe in der Region Chrudim}

Dem Studium der früh- und hochmittelalterlichen Besiedelung in der Region Chrudim widmen sich verhältnismäßig viele Forscher aus verschiedenen regionalen und überregionalen Institutionen. Den gegenwärtigen Erkenntnisstand über die mittelalterliche dörfliche Besiedelung im nördlichen von Niederungen geprägten Teil der Region Chrudim verdanken wir vor allem systematischen Oberflächensammlungen, welche die Kontinuität und Diskontinuität ab der frühmittelalterlichen Besiedelung bis in die Gegenwart insgesamt gut erfassen, was noch um zahlreiche historische Quellen ergänzt wird (für den nördlichen Teil der Region Chrudim vgl. Frolík-Sigl 1995). Nichtsdestoweniger kommt es nur selten zu einer Verifizierung der durch zerstörungsfreie Methoden gewonnenen Informationen, so etwa bei der Ausübung der archäologischen Denkmalpflege. Die auf die Forschung oder auf Prävention ausgerichteten destruktiven archäologischen Grabungen konzentrierten sich lediglich hauptsächlich auf Orte, die gegenwärtig die Ballungsraumzentren der Region bilden (z.B. Chrudim - übersichtliche Zusammenfassung siehe Frolík-Sigl 1998; Předhradí - Zusammenfassung des Kenntnisstandes siehe Frolík-Musil 2012; Hrochův Týnec - Zusammenfassung des Kenntnisstandes siehe Frolík-Musil 2011; Hlinsko - Frolík 1989; Skuteč - Zusammenfassung des Kenntnisstandes siehe Voráček et al. 2011, 1020; Luže - Zusammenfassung des Kenntnisstandes siehe Voráček et al. 2010, 28-38); Funde aus ländlicher Umgebung sind sehr selten (z.B. Dvakačovice - unveröffentlichter Komplex). Sehr bruchstückhaft ist unser Kenntnisstand über die mittelalterliche und frühneuzeitliche ländliche Besiedelung und ihr wirtschaftliches Hinterland was den überwiegend waldbedeckten Südteil der Region Chrudim betrifft, besonders in den Gebieten des Eisengebirges und der Saarer Berge (zum gegenwärtigen Kenntnisstand siehe Musil-Netolický 2014). Die Siedlungsgrundeinheit des Eisengebirges stellten Dörfer dar, die in einigen Fällen durch die Zentren einer größeren Grundherrschaft in Form von kleinen Städtchen ersetzt wurden (z.B. Ronov nad Doubravou, Bojanov, Nasavrky, Raná). Parallel zu diesem Modell muss mit einem Herrschaftssitz mit angrenzendem wirtschaftlichen Hinterland gerechnet werden. In dem waldbedeckten Raum des Eisengebirges trifft man zwei wesentliche Typen an. Der erste stellt die Verbindung einer Feste mit einem Wirtschaftshof dar, der eher für den von Niederungen geprägten Teil der Region Chrudim charakteristischer ist. Eine Ausnahme von dieser Regel stellt die Feste Stoupec mit angrenzendem Wirtschaftshof und Dorf dar. Dieses Faktum lässt sich jedoch durch die Notwendigkeit erklären, den Abbau von Eisenerz zu kontrollieren. Der zweite und häufiger anzutreffende Fall der Bindung eines Herrschaftssitzes an das wirtschaftliche Hinterland stellen Burgen mit angrenzendem wirtschaftlichen Hinterland in Form eines Vorwerks (Rabštejnek) oder weiteren Objekten dar (z.B. die Mühle unterhalb der Burg Strádov). Diese an einen Burgbau angrenzenden Höfe konnten bei einer günstigen politisch-wirtschaftlichen Situation zu einem kleinen Städtchen heranwachsen (z.B. Žumberk, Předhradí bei der Richenburg, Podhradí bei Burg Lichnice). Diese Struktur wurde noch um sog. Herrenhofdörfer ergänzt, die einen ungeordneten Grundriss hatten und auf Lichtungen entstanden, wobei ihre Entstehungszeit in unserem Interessengebiet in das 16. Jahrhundert gelegt wird (vgl. Štěpán 1995, 7; Štěpán-Šulc 2001, 9-10; Štěpán-RůžičkováŠulc 2003, 21). Nichtsdestoweniger ist es im Verlauf des 14. und 15. Jahrhunderts infolge von klimatischen Veränderungen, Kriegsereignissen und weiteren Faktoren besonders in den höher gelegenen Lagen zu einem Rückgang der Besiedelung gekommen. Einige Dörfer und Höfe sind schlagartig untergegangen, andere wurden nach und nach wüst oder wurden gegebenenfalls auf ein Anwesen oder einen einzeln stehenden Hof reduziert. 
Wenn wir unsere Erkenntnisse zusammenfassen, so haben wir auf einige gut dokumentierte Beispiele aus der Region des Eisengebirges hingewiesen, wobei sich folgende Grundtypen an Wirtschaftshöfen ausmachen lassen:

1. einzeln stehende Wirtschaftshöfe mit spärlicherer Dichte der Siedlungsstruktur,

2. einzeln stehende Wirtschaftshöfe, die durch die Rückbildung größerer Dörfer entstanden sind, 3. an Feudalsitze gebundene Wirtschaftshöfe: a) an eine Feste; b) an eine Burg (aus der zuletzt genannten Variante konnte auch eine Untertanenstadt entstehen).

Die vorliegende Studie ist Teilergebnis eines Projekts des Studentischen Förderwettbewerbs der Westböhmischen Universität in Pilsen Nr. SGS-2016-053 „Das wirtschaftliche Hinterland und die Umwelt von wüsten mittelalterlichen und neuzeitlichen Dorfsiedlungen - 2. Etappe“.

PhDr. Jan Musil, Regionální muzeum v Chrudimi, Široká 86, 53701 Chrudim, Katedra archeologie Filozofické fakulty Západočeské univerzity v Plzni, Sedláčkova 15, 30614 Plzeň, Česká republika, musil@muzeumcr.cz

Mgr. Petr Netolický, Katedra archeologie Filozofické fakulty Západočeské univerzity v Plzni, Sedláčkova 15, 30614 Plzeň, Česká republika,netolicky.petr@seznam.cz 